\author{
Chen-Yuh Wu, \\ RMIT University, Australia \\ ORCID ID, 0000-0001-8994-0645 \\ email: s3426331@student.rmit.edu.au \\ Iryna Heiets, \\ Ph.D., RMIT University, Australia \\ D ORCID ID, 0000-0003-1267-3790 \\ email: iryna.heiets@rmit.edu.au \\ Hanna Shvindina, \\ Dr.Sc., Sumy State University, Ukraine \\ (iD) ORCID ID, 0000-0003-0883-8361 \\ email: shvindina@management.sumdu.edu.ua
}

Corresponding author: shvindina@management.sumdu.edu.ua

\title{
BUSINESS MODEL MANAGEMENT OF LOW-COST CARRIERS: IN A SEARCH FOR THE IMPACT- FACTORS OF PERFORMANCE (CASE OF AIRASIA GROUP AIRLINES)
}

Abstract. The study is aimed at analysing how social and economic development indicators, global and regional economic indices are influencing low-cost carriers (LCC), AirAsia Group Berhad (AAGB) in particular. It is crucial not only to define the impact-factors, but to embed them in management framework for further decision-making. Passenger traffic is the main indicator of LCC performance, unlike the Full-Service Network Carriers (FNSC) that taking advantages on both passengers and freights. However, both categories depend on the macroenvironment and business environment dynamics, and KPls should be reconsidered to face the current global challenges. The global GDP, GDP per capita are commonly used to access the economic and social development trends, the passenger numbers per annum, unemployment rate and else are used to understand the status of operations in LLC performance management. This study deals with several overlapped categories of research, such as low-cost carriers business model, impact-factors of air transport development, global trends in several industries. The research methodology is combination of comparative analysis, correlation analysis, regression analysis and forecasting, using secondary data from annual reports and quaternary financial reports. The comparative analysis gave us the understanding of the general performance trend of the group and subsidiaries. One of the study components is the correlation analysis that revealed the most correlated factors for the economic development of $A A G B$, such as global GDP, regional GDP, regional GDP per capita, population growth. The global and regional dimensions were presented in the research to reveal what affects the airline performance the most. Global GDP is the most correlated indicator for the global and regional development within $A A G B$, and the regional GDP per capita comes the second by its significance. The population size has a great influence on performance indicators (globally and regionally), and if this indicator is taken into account for forecasting the potential growth is expected in the next five years. These findings enable to design the business-model of LLC more accurate in accordance to the forecast analysis towards innovative costs decisions.

Keywords: business model, management, KPI, performance management, Low-Cost Carrier, airline, AirAsia group, passenger traffic.

Introduction. Low-cost carriers (LCC) provide relatively low airfares and allow the customers to have a new option to travel. Several studies have been made to understand how LLCs are capable to cause a direct conflict with Full-service network carrier (FNSC). With the tremendous success since LCC appeared, the LLC are aiming to partitioning a portion of the market shares by assessing broader outlook by analysing the key performance indicators (KPI's), i.e. global economic and operation indicators.

Cite as: Wu, C.-Y., Heiets, I., \& Shvindina, H. (2020). Business Model Management of Low-Cost: in a Search for Impact-Factors of Performance (Case of AirAsia Group Airlines). Marketing and Management of Innovations, 2, 354-367. http://doi.org/10.21272/mmi.2020.2-26 
The majority of the studies conducted for airline business are focusing on both Europe and North America, two of the well-developed aviation markets. However, with the dramatic growth of the Asian economy, it was seldom been mentioned the carrier within the region. Therefore, the aim of this paper will be based on analysing the AirAsia Group Berhad (AAGB), regards to the group and individual entities' economical and operational performance. Furthermore, the paper is to figure out the relationship and impact to and from the global performance (i.e. GDP per capita, GDP and unemployment rate) within the group and subsidiaries.

This paper will begin with introducing the AAGB company structure with few of the subsidiaries, since the group has a several new airlines (i.e. AirAsia Cambodia, Sri Lanka) on coming and just launched (AirAsia Japan). Due to the research required few years of operational data to conduct study, therefore, the following three subsidiaries will be omitted for this study. Nonetheless, with the very few of their contribution to AAGB will result in a slight deviation to the estimation, but it can still be utilised as a rough guide to shareholders or investors.

Literature Review. Low-Cost Carrier. Several studies have sought to identify the low-cost carrier business model, Gillen \& Ashish (2004) defined and explained the original concept of LCC, which operates their network with short-haul point to point services at selected secondary airport. However, with such service, allowance for passenger to travel with connection traffic is disregarded due to being apart from the major airports, even though it's not totally disconnected but they must've do it by themselves. Scholars also stated the LCC business model is differentiated by; it conducts service under no-frill sector, which offers lower prices than general airlines and provide more accessibility to travellers, but less flexibility. Hence, most of customers are leisure and business passenger who weren't time-sensitive that has been drew from the characteristic of LCCs. Moreover, Carmona-Benitez \& Lodewijks (2008) detailed the main operation strategies for LCC based on Gillen \& Ashish's concept. By minimizing turnaround times and operation cost, same aircraft type, low flexibility, no beverages in flight, increasing the aircraft utilized hours, high density cabin configuration, outsourcing other than cabin crew (i.e. Ground staff) and without royal program. This strategy provide airline to have aggressive expansion. However, each LCC airline do differently, with some service included to provide customer satisfaction with not only cheap but great service (i.e. WestJet's airfare includes light snacks).

With the chaos and loses of trustworthiness to air transport after the 9/11 terrorist attack, CarmonaBenitez \& Lodewijks (2008) has noticed the profit margin reveals the LCCs of Ryanair and EasyJet relatively provide a steadier outcome than British Airways, the Full-Service Network Carrier (FNSC). However, it can't represent to all cases, but the 9/11 sure can represent the transition for LCC to participate more share of the monopolised airline market. With the potential enhancement of LCC's partitioning the demand, the growth is foreseen. Therefore, Forsyth (2007) has expected to experience the long-haul LCC flight to appear. However, Graham et al (2007) denies the expectation from Forsyth's concept but proved that some airlines like AirAsia X, MyTravel and Jetstar Australia who has already started to conduct longhaul low-cost flights. Moreover, the long-haul low-cost services it's anticipated that is more likely to attract pure leisure travellers only. The operator that focuses on such niche market must consider with the relatively low demand frequency will greatly affect the profitableness of one company (Wenseveen, 2007 \& Carmona-Benitez \& Lodewijks, 2008). Furthermore, Aldamari \& Fagan (2005) figured with such expansion of LCC, following the complexity of networks, the coverages starts to form as a Quasi Hub-andSpoke system. According to Carmona-Benitez \& Lodewijks (2008), LCC business model has made FSNC to double check their operation cost, with reduction of their unnecessary expenses may lead their price drop to roughly same level as the LCC. Furthermore, LCC are taking the Hub-and-Spoke network for operation, due to the increment of convenience to passenger for connection flight and able to expand their networks. According to De Witt \& Zuidberg (2012), Low-Cost Carrier (LCC) has been experiencing high competitiveness both in Europe and North America. Moreover, with the intensive competition, the trend of 
average route distance has been extended, in addition of frequencies reduction. Rely on this, its fare to state that LCCs are no-longer conducting the original concept by carry-out pure Short-Haul operation. Furthermore, the constraint from traffic density, result in LCCs adopting various method to ensure an organic growth for the future.

Barrett (2004), LCCs eliminated these hobbling costs by serving a point-to-point system, often operated from secondary airports at low fares. The increasing use of low-cost carrier services reflects customer preference for low fares and point-to-point travel, and a dislike of the congestion, confusion and long walking and waiting times at hub airports.

Dewitt \& Zuidberg (2012), LCCs have been able to cope with route density problems by generating new demand, as well as by attracting. Moreover, due to the colossal growth of LCC, some companies attempt to solve with the upcoming route density problem by adjusting route frequency, by selecting city pair markets with less price-sensitive demand, and by generating ancillary revenue. Scholar stated the LCC business model analyses usually focus on cost reductions and cost structure. Methods to generating additional incomes are; unbundling the traditional; all-inclusive airline product and offering unbundled low air fares, airlines can attract price-sensitive passengers to their secondary airport from even greater distances away. And they can also more effectively compete against the network carriers for higher yield passengers at the major airports.

Francis et al. (2007) deduce that the relative cost advantage of a long-haul no-frills operation is around $20 \%$, on the other hand, the advantage of short haul is above $50 \%$ or more.

Impact-Factors of Air Transport Development. Many studies have been conducted to analysis the correlation between the economic indicators and performance indices of air transportation. Previous studies have typically depended on static Ordinary Least Squares model, (Ba-Fail et al. 2000, Chin et al. 2001, Peterson 2007, Karlaftis 2008), Ba-Fail et al. (2000) analysed and forecasted the air travel market is a part of cooperate planning process in the UK and Saudi Arabia. The development model for domestic air traffic demand in the UK and Saudi Arabia was made with different combinations of explanatory variables using stepwise regression analysis.

Chin, Tay (2001) stated implication on investment decisions to profitability of Asian airlines. Likewise, scholars analysed their correlation between Air traffic growth with GDP growth in Asia Pacific region, investigated the region growth and profitability of the same region and identified how marketing strategy can be adopted to improve profitability in Asian airlines.

The correlation analysis was used to examine the investment patterns, regression metrices was analysis level of impact on passenger traffic growth to airline's profitability. This study has also shown that the Asian airlines generally obtain higher profit yet to have higher survival profitability, but the airlines shouldn't be aiming for over-necessary expansion of fleet in a hurry.

Peterson (2007) sought to provide insights into the relationship between economic growth and air freight industry.

Karlaftis (2008) investigated the general issue of forecasting demand in high season in regional airports in Greece. Scholar proposed a modelling combination, dynamic Tobit models using monthly passengers traffic data for a 20 -year period.

Although some studies (Chang \& Chang, 2009, Marazzo et al. 2010, Chi \& Beak, 2013, Hu et al. 2015, Phyoe, et al. 2016) test the correlation between air transport demand and economic growth in different countries.

Chang \& Chang (2009), investigated the relationship between air cargo transportation and economic growth in Taiwan, from 1974 to 2006 . The outcome of this article is the evidence of direct correlation between economic and air cargo expansion.

Marazzo, Scherre \& Fernandes (2010) investigated the nexus between Gross Domestic Product (GDP) and air passenger traffic in Brazil between 1966-2006. In this article, the econometric method 
proposed by Johansen and Juselius (1990) has been adopted for analysis of long-term equilibrium between variables, such as GDP and air transport traffic.

Scholars investigated co-integration, reaction to shocks and causality relationship between variables. They proposed an econometric approach which can be implemented as an input for air passenger traffic forecasting model comprising time series analysis in the air transportation industry. Likewise, they also presented the empirical evidence of air transport multiplier effect in the economy using Granger test and variance decomposition on cycle component.

Chi \& Baek (2013) has conducted a serial test to examine the effects in both long- and short-run of the economic growth on trafficking passengers and cargos in air within the US. By utilizing the autoregressive distributed lag (ARDL) to approach to cointegration what was invented by Pesaran et al. (2001). Before ARDL numerous studies adopted two types of methods, the Granger causality and impulse response analysis. However, both instruments were mainly focusing on the dynamics in short-term instead of figuring the long-term equilibrium. According to Hu et al. (2015), the economic growth and domestic air passenger traffic in China has shown a long-term equilibrium correlation. Scholars proven that each percentage raised in air passenger traffic has direct portion to have an increasing $0.934 \%$ of GDP in China. The impact of GDP, airfare, service level, travel time and population growth to passenger traffic demand in Singapore has been stated by Phyoe et al. (2016)

Impact of the Social or Economic Development to Aviation. This part of the study regards to the impact on either social or economic development in aviation, to the belonging country, to the region or the world. Whitelegg (2014) supported the concept by stating aviation industry is a fast-growing sector of the economic what associate with numbers of social and economic benefits. However, with certain growth of economy will result in direct proportional environmental impact, due to the greenhouse gases deposition and else. Nonetheless, the aggressive expansion on either air traffic or airports. Scholar mentioned with such inclining requirement have frequently supported by demand of employees to fulfil the growth. According to the study, the correlation between jobs and economic, has proved that raising employment rate can be used as one of the social development's indication, in accordantly, with the unemployment rate can also be an indication on same category. After considering the important factors, researcher believed will have reduction in air travel demand will have positive economic benefits. Dhingra \& Yadav (2018) attempted to summarise the development in LCC affecting the economic, also mentioned the future. Moreover, with the revenue that influence the economic development has showed to generate better competition with the open skies policy, subsidy, and ownership issues are explicitly addressed (Forsyth, King, \& Rodolfo, 2006). Major inference from the current studies shows that there is significant correlation among economic development \& LCC operations (Donzelli, 2010).

Methodology and research methods. Research methods combine several dimensions: comparative analysis, correlation analysis, regression analysis and forecasting of the outcomes. There are some data limitations that are discussed below. The data processing was done via SPSS Statistics. Oum \& Yu (1995) have demonstrate their method of conducting comparative analysis on 23 major airlines around the world, utilising data from 1986 to 1993, to acquire their productivity and unit cost index (UCl). Moreover, with the effect of input price changes on unit cost, gross total factor productivity (TFP) are also examined. Their result has revealed multiple discovers, what includes: (a) major European and some Asian carrier achieved tremendous productivity over North American counterparts; (b) the productivity gap between North American and other carriers have significant alleviate, etc. Furthermore, scholars have provided figures of Asia-Pacific, Europe and North American's performance of index over time on each major airline. It's clear that airlines like ANA and SAS have outstanding performance that receive near $2 \mathrm{UCl}$, however, all North American airlines has yet to achieve 1.5 UCl. In regional average, European airlines has the most stable outcome, on the other hand Asia-Pacific region has dramatically veered to have the lease performance on Singapore Airline overall in $\mathrm{UCl}$. 
Ahmed \& Khan (2011) studied the effectiveness of productivity on economic growth of Pakistan Airlines (PIA), Singapore Airlines (SIA) and Sri Lanka Airlines (ALK) over 1995-2009 by conducting comparative analysis. Scholar acquired the result to prove that the best performed in average employee productivity and stage length. ALK managed to have best unit cost and PIA required additional improvement on all three fields compare to others. This study utilised the descriptive methods to state various concepts related to airline productivity. Calculations of dividends on total operating revenue and aggregate traffic (RPK) resulted in seats sold times average stage length. Moreover, by dividing total operating expenses and aggregate productivity (ASK) will equal to seats produced multiple average stage length. Also, study has supported the calculation by partition productivity (ASK/ATK) on numbers of employees to acquired average employee productivity. As a result, specific recommendations are suggested for each airline in this study, yet to provide finding to support scholar's opinion. Khakpour (2013) stated the numbers of comparative research approaches, such as historical, social and methodological analysis, etc. providing strengths and weaknesses on each method. SWOT analysis, PEST analysis and Porter's Five Forces has been conducted in Rahman, Azad \& Mostari (2015). According to the findings, Scholars stated that Bimen Bangladesh Airlines with the situation of lack of resources, aircrafts and qualified personnel, it has successfully partitioning a respectable portion of market share in UK's highly compatible air travel industry in comparison to other major airliners. Rhman, Azd \& Mostari (2015) used quantitative research and qualitative research to provide more flexibility and versatility for this case study. In addition, by performing surveys to Bimen's passengers to acquired primary data, also support by secondary data from books, newspapers, internet and magazines.

According to Mukaka (2012), correlation is a statistical method to assess a possible linear association between two or more continuous variables. Correlation coefficient is main matrix which represents the strength of the putative linear association between the variables. Regularly, values will remain within the range between -1 to +1 , moreover, scenario in result with 0 reveals to nil linear relationship between two variables existed. Two main correlation analysis are introduced in Mukaka (2012), Spearsman's and Pearson's. However, Kendall's tau-b correlation coefficient hasn't be mentioned in the study. Pearson correlation coefficient uses when both variables being studied are normally distributed.

According to Taylor (1990), the correlation coefficient is referred to Pearson's r coefficient. The positive correlation coefficient means an increase in the first variable would corresponding to an increase in the second variable. On the other hand, the negative correlation coefficient indicates inverse relationship between two variables. Xiao et al (2016) presented three well-known correlation coefficient such as Pearson's, Spearman's and Kendall's, are compared from definition to application domain.

Bishara \& Hittner (2012) used twelve tests to identify the level of the significance of a correlation. Which includes Pearson t-test, z-test of Fisher r-to-z transformation, Spearman rank order correlation ttest, exact test, transformation box-cox, Yeo-Johnson, Arcsine and RIN, Resampling Permutation test, Univariate bootstrap test, Bivariate bootstrap test and Bivariate bootstrap with bias correlation and acceleration $(\mathrm{BCa})$ test.

Asuero, Sayago \&Gonzalez (2006) has presented the relationship between the coefficient of determination and multiple correlation coefficient, the covariance, the correlation coefficient and the coefficient of alienation, fir the case of two related variables $x$ and $y$. In addition, they explained the scatter plots and scatter diagrams. Explanation on coefficient of determination $R^{2} . R^{2}$ is equal to the ratio of the sum of squares accounted for by the regression ( $S S_{\text {Reg) }}$ to the total sum of quares of deviation about the mean (SYY) for a model with constant term (homoscedastic case, $w_{i}=1$ ). Goodwin \& Leech (2006) discussed six factors that affect the size of a correlation, including the amount of variability in the data, differences in the shapes of the 2 distributions, lack of linearity, the presence of 1 or more "outliners", characteristics of the sample and measurement error, also mentioned the ways to determine possibility of these factors affecting the correlation. 
Puth, Neuhausser \& Ruxton (2014) introduced the effectively using Pearson's coefficient correlation. And for this purpose, they presented several different methods. According to their results, all investigated methods performed similarly and there is no preferred or most recommended method overall.

Ghobbar \& Friend (2001) explained the method called Analysis of Variance (ANOVA) in regard to defining multiple attributable experimental factor and its interaction to the variation. As a reference to the result, scholars presented a summary of the General Linear Model (GLM) that used to calculate the pvalue for the main factors and both side's interaction. GLM is also demonstrated in the study, description point out the GLM is a candid extension of diverse regression allowing for multiple sole variables; that is, exploiting the relationship among dependent variable and independent variable to estimate or construe dependent variable's manifestation. However, due to multiple factors have to be researched and analyse in this case study, therefore, multiple regressions will be conducted to examine the figures to support the result. Thirteen different forecast methods regularly used by airlines were illustrated in Ghobbar \& Friend (2001), however, due to the intermittent demand that varies with numbers of factors leading to fluctuation in accuracy. Scholars has developed a method to conduct forecast projecting with issued intermittent demand can remain capable to evaluate the result, called Predictive Error-Forecasting Model (PEFM). Additionally, ICAO has published the Manuel on Air Traffic Forecasting in 2006. Methods of forecasting, what includes Quantitative, Qualitative and Decision-making, three main classes. First of all, in quantitative approach forecasting methods can be divided in to two different categories: Trend Projection and Decomposition methods, that includes cases like Exponential Smoothing, Box Jenkins, etc. with total of 5. Secondly, qualitative approach can be split in two: Delphi technique and Technological forecasting. Last but not least, Market research and industry survey, Probabilistic analysis, Bayesian analysis and System dynamics are in the sort of Decision-making analysis.

ICAO (2006) stated the forecasting sample was mainly focusing on the Global Gross Domestic Product (GDP) and airline Yields, moreover the dependent variables i.e. Revenue Passenger Kilometre (RPK). According to Jifri et al. (2017), dependent variable is sampled as load demand, etc. For independent variable are labelled with cases such as temperature, rainfall, population and GDPs.

Data Limitation. This study is performed by gathering the secondary data from AirAsia Group Airline's annual reports and quaternary financial report. However, some of the subsidiaries like AirAsia $X$ and AirAsia Indonesia only have data recorded since 2012. Also, AirAsia India as the latest established organization that opened in 2014, numbers has obtained ever since then. Furthermore, the rest subsidiaries have not released the financial status before 2009.

World Bank has listed multiple indicators from various sector. However, this study was based on the social and economic development that affect/influence on AAGB or conversely. Which includes adolescent fertility rate, children in employment, vulnerable employment rate and unemployment rate, etc. for social development. Furthermore, economy indicators include GDP, GDP growth, GDP per capita, inflation rate, import and export of goods, etc. However, research will be required to compare the result of forecasting between official released and own calculation. World bank as the main data provider is to offer actual volume for both types of indicators. However, to complete the following study, forecasted economy data from International Monetary Fund (IMF) has been applied. Consider to different organization's definition on geographical boundary in Asia and Asia Pacific region may varies. Therefore, the results may stand on dissimilar stage, but in order to achieve our research goal, minor inaccuracy with the digits and result must be considered.

Moreover, prices on fuel play a crucial role in global economy. The aviation industry is fully dependent on the petroleum. Nonetheless, the unstable fluctuation in fuel prices is uncontrollable to public, therefore exclusion in the fuel prices and the following exchange rate to USD\$ is adopted. Due to official trade between Organization of Petroleum Exporting Countries (OPEC) and else were united to exploit USD \$ as commerce currency. Hence, both significant elements will be omitted. 

of Performance (Case of AirAsia Group Airlines)

Results. The results will be divided into four parts as it was presented at methodology part: comparative analysis, correlation analysis, regression analysis and forecast analysis. Results on Comparative Analysis. In this part or research, we will be conducting the comparative analysis on ASK (productivity), RPK (Revenue Passenger Kilometers), No. Aircraft and Load Factor (LF) for the AirAsia Group Berhad's subsidiaries' performance outcome from 2015 and 2017(ASK \& RPK) and full data from 2009 to 2017 for fleet size and load factor.

\section{5}

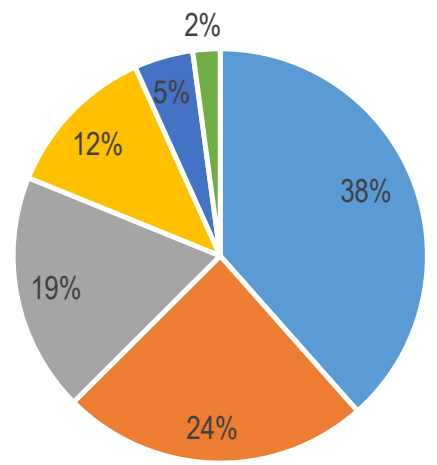

2017

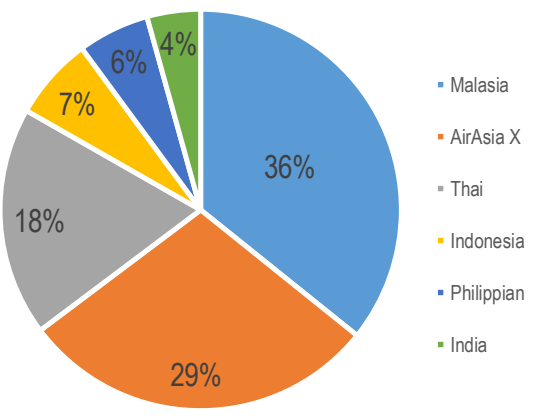

Figure 1. ASK in AirAsia Group in 2015 and 2017

Source: AirAsia, 2011-2018, Annual report.

Due to lack of data as mentioned in the data limitation regards to insufficient sources for the early days, hence, we can clearly identify the pie chart illustrate below has yet to have any obvious changes, however, most of the subsidiaries has a gradual reduction, Indonesia AirAsia especially. Furthermore, while others have had reduced their ASK in percentage, AirAsia X has evidentially increased. However, with the reduction in percentage, each subsidiary provides higher ASK than before, except Indonesia. This situation is in addition to support the smaller company such as India and Philippian have been expanding with an unforeseeable speed to acquire higher share.
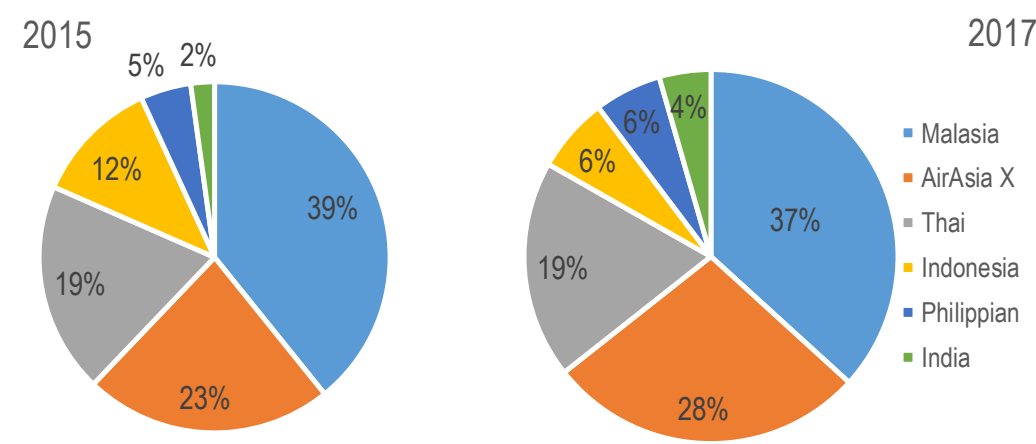

Figure 2. RPK in AirAsia Group in 2015 and 2017

Source: AirAsia, 2011-2018, Annual report.

Secondly, comparison to ASK and RPK is showing there has yet to have difference level of over two percent. In order to satisfy these figures without causing significant difference can briefly estimate the load factor in these air carriers are relatively high. 
C.-Y., Wu, I., Heiets, H., Shvindina. Business Model Management of Low-Cost Carriers: in a Search for the Impact-Factors of Performance (Case of AirAsia Group Airlines)

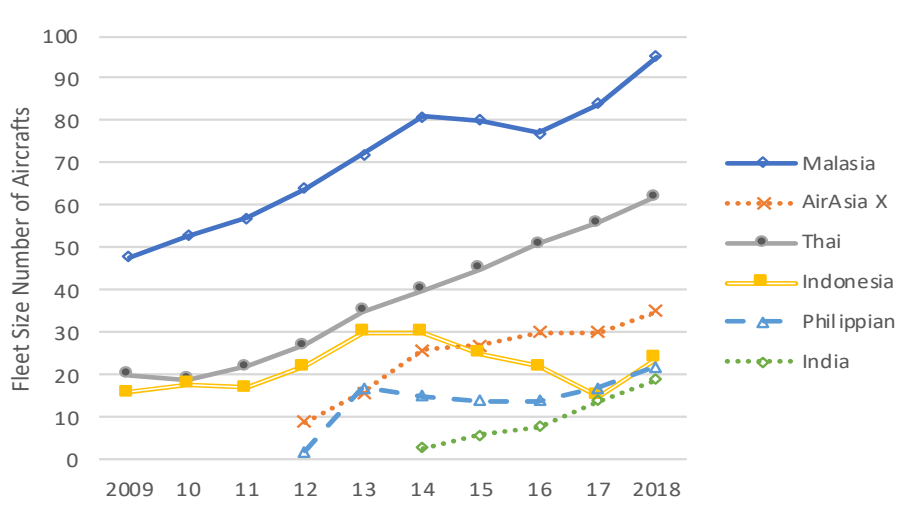

Figure 3. Each AirAsia Group Berhad's subsidiaries' Fleet size, units over year 2009-2018 Source: AirAsia, 2011-2018, Annual report.

The following figure shows the asset owned by each airline. AirAsia Malaysia as the main contributor to the number of aircrafts, yet AirAsia Thai remain on second. The total fleet size for the group has doubled the amount since 2009, which owned the number of 84 , by 2017 they have reached 186 .

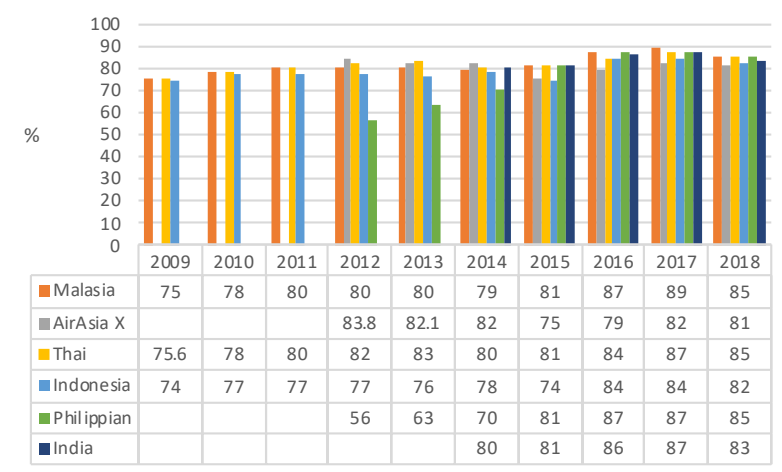

Figure 4. Each AirAsia Group Berhad's Subsidiaries' Load Factor (LF), \% over year 2009-2018 Source: AirAsia, 2011-2018, Annual report.

As estimated the relatively high load factor is supported by the ASK/RPK pie chart. Without such load factor at each company will have been documented with great variation in ASK/RPK. The highest load factor has been recorded from 2017 with achievement or near $90 \%$ of load factor done by AirAsia Malaysia (see the Fig. 4). On the other hand, AirAsia Indonesia's performance is relatively lower than others with rough average of $78 \%$. However, it's fair to say AirAsia Group Berhad has excellent performance over last 10 years. Results on Correlation Analysis. In this part of study, we investigated how social-economic development indicators affect the passenger traffic in AirAsia Group Berhad by conducting the Pearson's correlation analysis. Global GDP, Global GDP per capita, Global Inflation Rate, Import and Export of Goods were selected to conduct our analysis as the economic development factor. Furthermore, Global Population, International Tourism and Global Unemployment Rate were categories as social development factor. According to table 1, result for over 0.9 shows very high correlation between the variables. For global population has a correlation index of 0.919 , which represent the highest correlation overall. In addition, Global GDP and International tourism also have fairly high correlation of near 0.9 . 
C.-Y., Wu, I., Heiets, H., Shvindina. Business Model Management of Low-Cost Carriers: in a Search for the Impact-Factors of Performance (Case of AirAsia Group Airlines)

Table 1. Pearson's correlation analysis between passenger traffic in AAGB and Global socioeconomic indicators.

\begin{tabular}{|c|c|c|c|c|c|c|c|c|c|}
\hline GLOBAL & $\underset{0}{\longrightarrow}$ & 宇 & 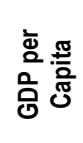 & 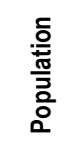 & 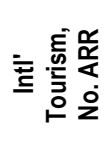 & 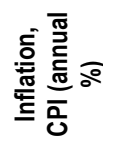 & 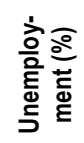 & 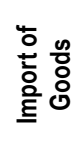 & 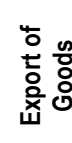 \\
\hline PAX & 1 & & & & & & & & \\
\hline Global GDP & 0.881 & 1 & & & & & & & \\
\hline Global GDP per Capita & 0.800 & 0.974 & 1 & & & & & & \\
\hline Global Population & 0.919 & 0.903 & 0.784 & 1 & & & & & \\
\hline Global Intl' Tourism, No. ARR & 0.878 & 0.872 & 0.745 & 0.984 & 1 & & & & \\
\hline Global Inflation, CPI (annual \%) & -0.729 & -0.551 & -0.417 & -0.731 & -0.688 & 1 & & & \\
\hline Global Unemployment (\%) & -0.108 & -0.184 & -0.180 & -0.140 & -0.282 & -0.170 & 1 & & \\
\hline Global Import of Goods & 0.812 & 0.972 & 0.995 & 0.787 & 0.754 & -0.444 & -0.227 & 1 & \\
\hline Global Export of Goods & 0.844 & 0.983 & 0.987 & 0.833 & 0.808 & -0.479 & -0.263 & 0.995 & 1. \\
\hline
\end{tabular}

Source: developed by the authors based on WorldBank Data, AirAsia, 2011-2018, Annual report.

On the other hand, Global inflation and Global unemployment have negative effect to passenger traffic in AAGB between each.

Table 2. Pearson's correlation analysis between passenger traffic in AAGB and Asian Pacific Region's (APR) socio-economic indicators.

\begin{tabular}{|c|c|c|c|c|c|c|c|c|c|}
\hline Socio-economic indicators & 衷 & $\begin{array}{l}\text { 离 } \\
\text { 品 }\end{array}$ & 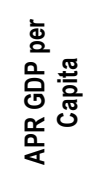 & $\begin{array}{l}\text { 을 } \\
\frac{\pi}{\overline{0}} \\
\frac{0}{0} \\
\frac{\alpha}{\alpha} \\
\frac{\alpha}{\alpha}\end{array}$ & 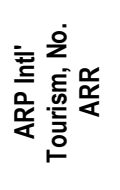 & 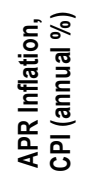 & 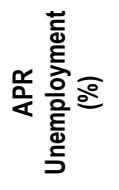 & 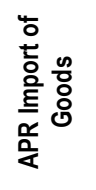 & 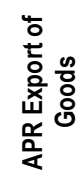 \\
\hline$\overline{P A X}$ & 1 & & & & & & & & \\
\hline APR GDP & 0.9247 & 1.0000 & & & & & & & \\
\hline APR GDP per Capita & 0.9202 & 0.9988 & 1.0000 & & & & & & \\
\hline APR Population & 0.9190 & 0.9543 & 0.9387 & 1.0000 & & & & & \\
\hline ARP Intl' Tourism, & 0.8789 & 0.9169 & 0.8968 & 0.9838 & 1.0000 & & & & \\
\hline APR Inflation & -0.5980 & -0.5280 & -0.5108 & -0.6245 & -0.5880 & 1.0000 & & & \\
\hline APR Unemployment & -0.3180 & -0.3566 & -0.3563 & -0.3056 & -0.3964 & 0.3606 & 1.0000 & & \\
\hline APR Import of Goods & 0.8124 & 0.9213 & 0.9336 & 0.7872 & 0.7547 & -0.2735 & -0.4150 & 1.0000 & \\
\hline APR Export of Goods & 0.8442 & 0.9439 & 0.9521 & 0.8332 & 0.8087 & -0.3116 & -0.4321 & 0.9950 & 1 \\
\hline
\end{tabular}

Source: developed by the authors on the basis of WorldBank Data, AirAsia, 2011-2018, Annual report.

Following the interpretation mentioned in the last chapter, for AirAsia's region result GDP, GDP per capita and population have a very high correlation with passenger traffic in AAGB. International tourism is also having high correlation to group's passenger traffic. Again, inflation and unemployment rate in the region shows moderate and low negative effect to AAGB.

After stating the correlation between passenger traffic to the world's socio-economic indicators then shrinking down to regional. This section will be revealing how will passenger traffic perform with airline's performance indicator.

Numbers of passenger traffic directly affect airline performance. However, in reference to table 3 , none of the performance indicator fulfilled very high correlation between each. Nonetheless, four out of six of the variables selected has scored high positive correlation that between $0.7-0.9$. Interpretation shows the passenger traffic has great correlation with most of the indicators, that proposed the numbers in passenger traffic will affect direct proportion to these indicators. 
C.-Y., Wu, I., Heiets, H., Shvindina. Business Model Management of Low-Cost Carriers: in a Search for the Impact-Factors of Performance (Case of AirAsia Group Airlines)

Table 3. Pearson's correlation analysis between passenger traffic in AAGB and its performance indicators.

\begin{tabular}{|c|c|c|c|c|c|c|c|}
\hline & PAX & Pax LF\% & RPK & ASK & Fleet & No. Dept & $\begin{array}{c}\text { No. } \\
\text { Employees }\end{array}$ \\
\hline PAX & 1 & & & & & & \\
\hline Pax LF\% & 0.6060 & 1 & & & & & \\
\hline RPK & 0.8191 & 0.881 & 1 & & & & \\
\hline ASK & 0.8522 & 0.8392 & 0.9952 & 1 & & & \\
\hline Fleet & 0.8671 & 0.7111 & 0.9523 & 0.9723 & 1 & & \\
\hline No. Dept & 0.8510 & 0.8015 & 0.9875 & 0.9964 & 0.9865 & 1 & \\
\hline No. Employees & 0.4591 & 0.8771 & 0.8768 & 0.8421 & 0.7707 & 0.8354 & 1 \\
\hline
\end{tabular}

Source: developed by the authors on the basis of AirAsia, 2011-2018, Annual report.

Results on Regression Analysis. By following the correlation analysis' result, we have received a great outcome, therefore, designation on the dependent factor (Passenger) and independent factors (Global Population, Regional GDP, Regional GDP per capita and Regional Population) through a regression test to seek for how it falls within the plot (see table 4).

Table 4. Regression analysis in AAGB

\begin{tabular}{lcccc}
\hline \multicolumn{4}{c}{ Regression Statistics } & \\
\hline Intercept & Coefficients & Standard Error & t Stat & P-value \\
Global Population & 24723758072.7379 & 8496350416.8552 & 2.9099 & 0.0270 \\
APR GDP & 5.1584 & 1.5920 & 3.2402 & 0.0177 \\
APR GDP per Capita & -0.0001 & 0.0000 & -3.7501 & 0.0095 \\
APR Population & 254252.1985 & 66144.3041 & 3.8439 & 0.0085 \\
\hline
\end{tabular}

Source: developed by the authors.

In the result of regression analysis multiple $r$ and $r^{2}$ equals to 0.985687303 and 0.97157946 . With the sum of such figures indicates that the observation falls on the regression line. This research will be following the forecasting model studied in the ICAO published forecasting model, formula as presented below:

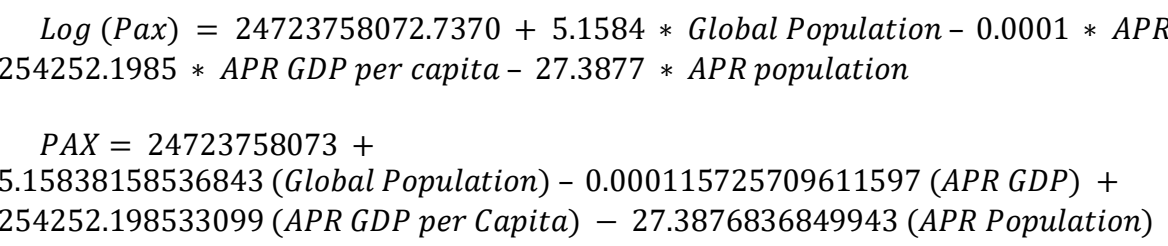

Table 5. Regression analysis in Passenger and global population.

\begin{tabular}{lrrrr}
\hline & Coefficients & Standard Error & \multicolumn{1}{c}{ t Stat } & P-value \\
\hline Intercept & -355874630.51917 & 55416558 & -6.42181 & 0.000122106 \\
Global Population & 0.054646529345908 & 0.007796 & 7.009464 & $6.25904 \mathrm{E}-05$ \\
\hline
\end{tabular}

Source: developed by the authors

Results on Forecast analysis. By following the regression analysis's result, we would be able to utilize the same model to forecast the upcoming outcome in the close future. However, to obtain the answers for this research we would only be using global population as sole factor. Due to the research were set to mainly focus on the passenger traffic in AAGB. Also, in addition to acquire the forecasted data of regional GDP and GDP per capita, sources from International Monetary Fund (IMF) are used. Due to inconsistent data sources (World Bank \& IMF) and regional coverage in countries varies, consequences of inaccuracy 
C.-Y., Wu, I., Heiets, H., Shvindina. Business Model Management of Low-Cost Carriers: in a Search for the Impact-Factors of Performance (Case of AirAsia Group Airlines)

may occur. Formula and actual calculations are shown below:

$$
\begin{aligned}
& \log (\text { Pax })+\text { Intercept }+ \text { Global Population } \\
& \text { Pax }=-355874630.51917+0.054646529345908 \text { (Global Population) }
\end{aligned}
$$

According to the trend, AAGB has a constant growing trend of around $10-20 \%$ since 2007 . However, year 2007 to 2008 and 2009 to 2010, AAGB achieved the most significant result in the last decade, which have doubled and nearly doubled the total passengers from the previous year.

Conclusions. The performance of LLC could be affected by various factors, starting from macroenvironment and micro-environment to internal causes. Every variable influences the rest causing a butterfly effect to elicit to different results. Firstly, we've discovered the most correlated indicator for both global and regional to economic development within AAGB. According to table 1, global GDP reveals the most signification correlation to group passenger with 0.881. Yet, regional GDP, regional GDP per capita have shown very high correlations to AAGB's passenger traffic.

Secondly, population have accounted the greatest influence on passenger traffic in AAGB for both globally and regionally. In global correlation analysis, population even performed higher outcome as a social economic indicator than another economic indicator.

Thirdly, as we stated in the forecast analysis' section, global and countries' population is the main factor to forecast the passenger traffic in AAGB. Lastly, it is expected to have a minimum of at least $5 \%$ growth in total passengers in the next five years till 2023.

However, both global and Asia's passenger forecasting study performed by IATA shows the potential growth of $3.9 \%$ each year. In comparison to IATA's result, we have acquired additional outcome and sanguinely anticipate AAGB not only fulfil but also carry out their operations and performed better than predicted. The findings of current research can be used in the performance management, for instance, if there is the growth of traffic is expected, the logistic should be reconsidered, maintenance costs and other significant parameters of business should be taken into account in further decision-making. The innovations can take place if the R\&D costs will be increased due to resources allocation. All these decisions are manageable under the accurate performance evaluation as it was performed. The focus of low-costs business model is perceived only as cost-oriented decisions system, but at the same time the costs reduction tends to be innovative by their nature. Innovativeness of costs decisions in management of low-cost may be a further direction of research.

Author contributions: conceptualization, methodology, supervision, writing-original draft I. H.; formal analysis, investigation, software, writing-original draft W. C-Y.; writing-review and editing, writing-second draft H. S.

Funding: This research received no external funding

\section{References}

Abed, S. Y., Ba-Fail, A. O., \& Jasimuddin, S. M. (2001). An econometric analysis of international air travel demand in Saudi Arabia. Journal of air transport management, 7(3), 143-148. [Google Scholar] [CrossRef]

Ahmad, K., \& Khan, M. M. (2011). A comparative analysis of productivity of airline industry: Evidence from selected Asian airlines. International Journal of Business and Social Science, 2(15), 224-230. [Google Scholar]

Ahmad, R., \& Neal, M. (2006). AirAsia: The Sky's the Limit. Asian Journal of Management Cases, 3(1), 25-50. [Google Scholar] [CrossRef

AirAsia. (2011). Annual report 2010. Retrieved from https://ir.airasia.com/misc/ar2010.pdf

AirAsia. (2012). Annual report 2011. Retrieved from https://ir.airasia.com/misc/ar2011.pdf

AirAsia. (2013). Annual report 2012. Retrieved from https://ir.airasia.com/misc/ar2012.pdf

AirAsia. (2014). Annual report 2013. Retrieved from https://ir.airasia.com/misc/ar2013.pdf

AirAsia. (2015). Annual report 2014. Retrieved from https://ir.airasia.com/misc/ar2014.pdf 
C.-Y., Wu, I., Heiets, H., Shvindina. Business Model Management of Low-Cost Carriers: in a Search for the Impact-Factors of Performance (Case of AirAsia Group Airlines)

AirAsia. (2016). Annual report 2015. Retrieved from https://ir.airasia.com/misc/ar2015.pdf

AirAsia. (2017). Annual report 2016. Retrieved from https://ir.airasia.com/misc/ar2016.pdf

AirAsia. (2018). Annual report 2017. Retrieved from https://ir.airasia.com/misc/ar2017.pdf

Albers, S., Baum, H., Auerbach, S., \& Delfmann, W. (Eds.). (2017). Strategic management in the aviation industry. Taylor \& Francis. [Google Scholar]

Alekseev, K. P. G., \& Seixas, J. M. (2002, November). Forecasting the air transport demand for passengers with neural modelling In VII Brazilian Symposium on Neural Networks, 2002. SBRN 2002. Proceedings. (pp. 86-91). IEEE. [Google Scholar] [CrossRef]

Asuero, A. G., Sayago, A., \& Gonzalez, A. G. (2006). The correlation coefficient: An overview. Critical reviews in analytical chemistry, 36(1), 41-59. [Google Scholar] [CrossRef]

Benitez, R. B. C., Paredes, R. B. C., Lodewijks, G., \& Nabais, J. L. (2013). Damp trend Grey Model forecasting method for airline industry. Expert Systems with Applications, 40(12), 4915-4921. [Google Scholar] [CrossRef]

Bishara, A. J., \& Hittner, J. B. (2012). Testing the significance of a correlation with nonnormal data: comparison of Pearson, Spearman, transformation, and resampling approaches. Psychological methods, 17(3), 399. [Google Scholar] [CrossRef]

Carmona Benitez, R. B., \& Lodewijks, G. (2008). Literature review of the passenger airline business models: Full service carrier low-cost carrier and charter airlines. In 10th TRAIL Congress: TRAIL in Perspective. Transport, Infrastructure and Logistics (TRAIL). [Google Scholar]

Chi, J., \& Baek, J. (2013). Dynamic relationship between air transport demand and economic growth in the United States: A new look. Transport Policy, 29, 257-260. [Google Scholar] [CrossRef]

Chin, A. T., \& Tay, J. H. (2001). Developments in air transport: implications on investment decisions, profitability and survival of Asian airlines. Joumal of Air Transport Management, 7(5), 319-330. [Google Scholar] [CrossRef]

Daft, J., \& Albers, S. (2012). A profitability analysis of low-cost long-haul flight operations. Journal of Air Transport Management, 19 49-54. [Google Scholar] [CrossRef]

Daft, J., \& Albers, S. (2013). A conceptual framework for measuring airline business model convergence. Journal of Air Transport Management, 28, 47-54. [Google Scholar] [CrossRef]

de Wit, J. G., \& Zuidberg, J. (2012). The growth limits of the low cost carrier model. Journal of Air Transport Management, 21, 1723. [Google Scholar] [CrossRef]

Demydyuk, G. (2011). Choosing financial key performance indicators: the airline industry case. In Winter Global Conference on Business and Finance (GCBF) (p. 2). [Google Scholar]

Dobruszkes, F. (2006). An analysis of European low-cost airlines and their networks. Journal of Transport Geography, 14(4), 249-

264. [Google Scholar] [CrossRef]

Fageda, X., Suau-Sanchez, P., \& Mason, K. J. (2015). The evolving low-cost business model: Network implications of fare bundling and connecting flights in Europe. Joumal of Air Transport Management, 42, 289-296. [Google Scholar] [CrossRef]

Fedosova, A. (2016). Comparison between Low-cost and Traditional Airlines. Case study: easyJet and British Airways. [Google Scholar]

Fehrm, B. (2018). Is Long-Haul LCC viable?. Leeham News and Analysis, March 28. Retrieved from https://leehamnews.com/2018/03/28/is-long-haul-lcc-viable/

Ghobbar, A. A., \& Friend, C. H. (2003). Evaluation of forecasting methods for intermittent parts demand in the field of aviation: a predictive model. Computers \& Operations Research, 30(14), 2097-2114. [Google Scholar] [CrossRef]

Goossens, Y., Mäkipää, A., Schepelmann, P., Van de Sand, I., Kuhndt, M., \& Herrndorf, M. (2007). Alternative progress indicators to Gross Domestic Product (GDP) as a means towards sustainable development. Beyond GDP, 305. [Google Scholar]

Henriksen, L. F., \& Ponte, S. (2018). Public orchestration, social networks, and transnational environmental governance: Lessons from the aviation industry. Regulation \& governance, 12(1), 23-45. [Google Scholar] [CrossRef]

https://www.iata.org/publications/economics/Pages/index.aspx/

Hu, Y., Xiao, J., Deng, Y., Xiao, Y., \& Wang, S. (2015). Domestic air passenger traffic and economic growth in China: Evidence from heterogeneous panel models. Joumal of Air Transport Management, 42, 95-100. [Google Scholar] [CrossRef

IATA Economics. (2018). Air cargo improved in May, but a full recovery will take time. Retrieved from

IATA. (2017). Economic performance of the airline industry. Retrieved from https://www.iata.org/en/iatarepository/publications/economic-reports/airline-industry-economic-performance---2017-mid-year--report'

ICAO. (2006). Manuel on Air Traffic Forecasting. Retrieved from

https://www.icao.int/MID/Documents/2014/Aviation\%20Data\%20Analyses\%20Seminar/8991 Forecasting en.pdf

Ismail, N. A., \& Jenatabadi, H. S. (2014). The influence of firm age on the relationships of airline performance, economic situation and internal operation. Transportation Research Part A: Policy and Practice, 67, 212-224. [Google Scholar] [CrossRef]

Jenatabadi, H. S., \& Ismail, N. A. (2007). The determination of load factors in the airline industry. International Review of Business Research Papers, 3(4), 125-133. [Google Scholar]

Jiang, H. (2013). Service quality of low-cost long-haul airlines-The case of Jetstar Airways and AirAsia X. Journal of Air Transport Management, 26, 20-24. [Google Scholar] [CrossRef

Jifri, M. H., Hassan, E. E., \& Miswan, N. H. (2017, October). Forecasting performance of time series and regression in modeling electricity load demand. In 2017 7th IEEE International Conference on System Engineering and Technology (ICSET) (pp. 12-16). IEEE. [Google Scholar] [CrossRef] 
C.-Y., Wu, l., Heiets, H., Shvindina. Business Model Management of Low-Cost Carriers: in a Search for the Impact-Factors of Performance (Case of AirAsia Group Airlines)

Jones, D. (2002). Cutting costs in Asia. Airfinance Journal, 38(250), 31-33.

Khakpour, A. (2013). Methodology of comparative studies in education. Contemporary Educational Researches Journal, 2(1), 2026. [Google Scholar]

Kua, J., \& Baum, T. (2004). Perspectives on the development of low-cost airlines in South-east Asia. Current Issues in Tourism, 7(3), 262-276. [Google Scholar] [CrossRef]

Lawton, T. C., \& Solomko, S. (2005). When being the lowest cost is not enough: Building a successful low-fare airline business model in Asia. Journal of Air Transport Management, 11(6), 355-362. [Google Scholar] [CrossRef]

Lin, C. K. E. (2010). Low cost carrier-airport relationship development in Southeast Asia (Doctoral dissertation, The Hong Kong Polytechnic University). [Google Scholar]

Liu, A. M., Yi, S., \& Yuan, S. S. (2018, April). The Developing Model of Aviation Economy to Support the Destination as a Hub City. In 2018 International Conference on Education Reform and Management Science (ERMS 2018). Atlantis Press. [Google Scholar] [CrossRef]

Malighetti, P., Paleari, S., \& Redondi, R. (2009). Pricing strategies of low-cost airlines: The Ryanair case study. Journal of Air Transport Management, 15(4), 195-203. [Google Scholar] [CroosRef]

Marazzo, M., Scherre, R., \& Fernandes, E. (2010). Air transport demand and economic growth in Brazil: A time series analysis. Transportation Research Part E: Logistics and Transportation Review, 46(2), 261-269. [Google Scholarl [CrossRef]

Mehmood, B. Shahid, A., \& llyas, S. (2015). Co-integration analysis of aviation demand and economic growth in Philippines. International Journal of Economics and Empirical Research (IJEER), 3(6), 271-277. [Google Scholar]

Mukaka, M. M. (2012). A guide to appropriate use of correlation coefficient in medical research. Malawi medical journal, 24(3), 69-

71. [Google Scholar]

Nam, K., \& Schaefer, T. (1995). Forecasting international airline passenger traffic using neural networks. The Logistics and Transportation Review, 31(3), 239-252. [Google Scholar]

OECD. (2019) Economic Outlook for Southeast Asia, China and India; Towards Smart Urban Transportation. Retrieved from https://www. oecd-library.org/development/economic-outlook-for-southeast-asia-china-and-india-2019 saeo-2019-en

Oum, T. H., \& Yu, C. (1995). A productivity comparison of the world's major airlines. Journal of Air Transport Management, 2(3-4), 181-195. [Google Scholar] [CrossRef]

Pender, L., \& Baum, T. (2000). Have the frills really left the European airline industry?. International Journal of Tourism Research, 2(6), 423-436. [Google Scholar] [CrossRef]

Pereira, B. A., \& Caetano, M. (2015). A conceptual business model framework applied to air transport. Joumal of Air Transport Management, 44, 70-76. [Google Scholar] [CrossRef]

Pereira, B. A., \& Caetano, M. (2017). Business model innovation in airlines. International Journal of Innovation: IJI Journal, 5(2), 184-198. [Google Scholar] [CrossRef]

Profillidis, V., \& Botzoris, G. (2015). Air passenger transport and economic activity. Journal of Air Transport Management, 49, 2327. [Google Scholar] [CrossRef]

Pulina, M., \& Cortés-Jiménez, I. (2010). Have low-cost carriers influenced tourism demand and supply? The case of Alghero, Italy. Tourism Analysis, 15(6), 617-635. [Google Scholarl [CrossRef]

Puth, M. T., Neuhäuser, M., \& Ruxton, G. D. (2014). Effective use of Pearson's product-moment correlation coefficient. Animal behaviour, 93, 183-189. [Google Scholar] [CrossRef]

Rahman, K., Azad, S., \& Mostari, S. (2015). A Competitive Analysis of the Airline Industry: A Case Study on Biman Bangladesh Airlines. IOSR Journal of Business and Management, 17(4), 23-33.

Rengaraju, V. R., \& Arasan, V. T. (1992). Modeling for air travel demand. Joumal of Transportation Engineering, 118(3), 371-380. [Google Scholar]

Ricart, J. E., \& Wang, D. (2005). Now everyone can fly: Air Asia. Asian Journal of Management Cases, 2(2), 231-255. [Google Scholar] [CrossRef]

Sengur, Y., \& Sengur, F. K. (2017). Airlines define their business models: a content analysis. World Review of Intermodal Transportation Research, 6(2), 141-154. [CrossRef] [CrossRef]

Shuk-Ching Poon, T., \& Waring, P. (2010). The lowest of low-cost carriers: the case of AirAsia. The Intemational Journal of Human Resource Management, 21(2), 197-213. [Google Scholar] [CrossRef]

Soyk, C., Ringbeck, J., \& Spinler, S. (2018). Revenue characteristics of long-haul low cost carriers (LCCs) and differences to fullsenvice network carriers (FSNCs). Transportation Research Part E: Logistics and Transportation Review, 112, 47-65. [Google Scholar] [CrossRef]

Srisaeng, P., Baxter, G. S., \& Wild, G. (2014). The evolution of low cost carriers in Australia. Aviation, 18(4), 203-216. [Google Scholar] [CrossRef]

Srisaeng, P., Baxter, G. S., \& Wild, G. (2015). Forecasting demand for low cost carriers in Australia using an artificial neural network approach. Aviation, 19(2), 90-103. [Google Scholar] [CrossRef]

Taylor, R. (1990). Interpretation of the correlation coefficient: a basic review. Journal of diagnostic medical sonography, 6(1), 35-39. [Google Scholar] [CrossRef] 
C.-Y., Wu, I., Heiets, H., Shvindina. Business Model Management of Low-Cost Carriers: in a Search for the Impact-Factors of Performance (Case of AirAsia Group Airlines)

Thomas, G. (2002). Asia's absent revolution: no-frills airlines are flourishing across north america and europe but not in ASIA. ATW: Air Transport World. [Google Scholar]

Turner, J. R., \& Thayer, J. (2001). Introduction to analysis of variance: design, analyis \& interpretation. Sage Publications. [Google Scholar]

Wang, J., Bonilla, D., \& Banister, D. (2016). Air deregulation in China and its impact on airline competition 1994-2012. Journal of Transport Geography, 50(C), 12-23. [Google Scholar] [CrossRef]

Wang, K., Zhang, A., \& Zhang, Y. (2018). Key determinants of airline pricing and air travel demand in China and India: Policy, ownership, and LCC competition. Transport Policy, 63, 80-89. [Google Scholar] [CrossRef]

Wensveen, J. G., \& Leick, R. (2009). The long-haul low-cost carrier: A unique business model. Journal of Air Transport Management, 15(3), 127-133. [Google Scholar] [CrossRef]

Williams, A. (2016). Contemporary Issues Shaping China's Civil Aviation Policy: Balancing International with Domestic Priorities. Routledge. [Google Scholar]

World Bank Data. (2018). Global indicators world. Retrieved from https://data.worldbank.org/indicator/NY.GDP.MKTP.CD/

Xiao, C., Ye, J., Esteves, R. M., \& Rong, C. (2016). Using Spearman's correlation coefficients for exploratory data analysis on big dataset. Concurrency and Computation: Practice and Experience, 28(14), 3866-3878. [Google Scholarl [CrossRef

Yadav, M., \& Dhingra, T. (2018). Recent developments in'low cost carrier'research: a review. International Journal of Business Excellence, 16(4), 427-453. [Google Scholar] [CrossRef]

Yeung, S., Tsang, N., \& Lee, Z. (2012). An importance-performance analysis of low cost carriers in asia. International journal of hospitality \& tourism administration, 13(3), 173-194. [Google Scholar] [CrossRef]

Zhang, A., Hanaoka, S., Inamura, H., \& Ishikura, T. (2017). Low-cost carriers in Asia: Deregulation, regional liberalization and secondary airports. In Low Cost Carriers (pp. 55-69). Routledge.

Чен-Юх Ву,

Мельбурнський Королівський Технологічний Університет (RMIT), Австралія

Ірина Геєць,

Ph.D., Мельбурнський Королівський Технологічний Університет (RMIT), Австралія

Ганна Швіндіна,

доктор економічних наук, Сумський державний університет, Україна

Управління бізнес-моделлю перевізників «лоу-кост»: у пошуках імпакт-факторів ефективності (кейс AisAsia Group Airlines)

Дослідження спрямовано на аналіз того, як показники соціального та економічного розвитку, глобальні та регіональні економічні показники впливають ефективність лоу-кост перевізників (LCC), зокрема AirAsia Group Berhad (AAGB). Важливо не лише визначити фактори впливу, а й закласти їх у структуру управління для подальшого прийняття рішень. Пасажирські перевезення є основним показником ефективності LCC, на відміну від мережевих перевізників повного обслуговування (FNSC), які використовують переваги як перевезення пасажирів, так і вантажних перевезень. Однак обидві категорії залежать від макросередовища та динаміки бізнес-середовища, і ключові показники есфективності (KPI) слід переглянути, щоб вирішити поточні глобальні виклики. Глобальний ВВП, ВВП на душу населення широко використовуються для вивчення економічних та соціальних трендів, кількість пасажирів на рік, рівень безробіття та інші використовуються для розуміння стану функціонування та ефекктивності управління лоу-костами у цьому дослідженні розглядається декілька категорій, що пересікають один одну, такі як бізнес-модель лоу-костів, фактори впливу розвитку повітряного транспорту, глобальні тенденції розвитку декількох галузей. Методологія дослідження - це поєднання порівняльного аналізу, кореляиійного аналізу, регресійного аналізу та прогнозування, на основі вторинних даних з річних та квартальних фінансових звітів. Порівняльний аналіз дав нам зрозуміти загальну тенденцію діяльності групи та дочірніх підприємств. Одним із компонентів дослідження $є$ кореляційний аналіз, який виявив найбільш корельовані фактори економічного розвитку $A A G B$, такі як глобальний ВВП, регіональний ВВП, регіональний ВВП на душу населення, приріст населення. У дослідженні були представлені глобальний та регіональний аспекти, щоб виявити, що найбільше впливає на роботу авіакомпанії. Глобальний ВВП $є$ найбільш корельованим показником для глобального та регіонального розвитку для $A A G B$, а регіональний BBП на душу населення стає другим за своєю значимістю. Чисельність населення має великий вплив на показники ефективності (в усьому світі та на регіональному рівні), і якщо цей показник буде врахований для прогнозування, потенційний приріст очікується в найближчі п'ять років. Ці висновки та прогнози дають змогу більш точно розробити бізнес-модель для подальшого ефективного управління лоу-кост перевізниками, спрямовану на інноваційні рішення в області управління витратами.

Ключові слова: бізнес-модель, управління, менеджмент, KPI, управління ефективністю, лоу-кост перевізник, авіакомпанія, група AirAsia, пасажиропотоки.

Manuscript received: 06.12.2019

(C) The author(s) 2020. This article is published with open access at Sumy State University 